Ana Zdravkova
Master in Industrial design and marketing
University of Cyril and Methodius
Faculty of Mechanical Engineering
Republic of North Macedonia
Ile Mircheski
Associate Professor
University of Cyril and Methodius
Faculty of Mechanical Engineering
Republic of North Macedonia
Sofija Sidorenko
Full Professor
University of Cyril and Methodius
Faculty of Mechanical Engineering
Republic of North Macedonia

Ana Zdravkova

\section{Bio-Inspired Approach for Innovative Design of Knee Protectors for Recreational Sports}

In this paper the process of an innovative design of a knee protector is presented. The main goal of the research was to find a creative design solution for more efficient protective equipment for light recreational sports. The research is based on an interdisciplinary approach where the possibilities of ergonomics and bionics methods were applied. In order to recognize and provide proper design requirements a valuable market research in the field of knee protector products was performed. An ergonomic research was implemented with intention to define the detailed requirements for more comfort, better functioning and better protection from injuries. The design process was completed following the problemdriven bio-inspiration approach. The armadillo's shell structure, consisted of tiles connected with collagen fibers, was an inspiration for an innovative design approach. The result is a virtual 3D model of an innovative design of a knee protector, with intention to be further developed and tested as a $3 D$ printed prototype, until achieving the phase of final product.

Keywords: Armadillo, Bionics, Ergonomics, Industrial Design, Knee protector.

\section{INTRODUCTION}

Sport inflicted injuries are very common when conducting a specific indoor or outdoor sport, whilst either avoiding a more serious mishap or due to a faulty performance. In order to reduce the injuries, the sportists are recommended to use protective equipment (protective gear). Depending on the complexity of the movements during practicing sport the protective equipment itself can cause compression or convulsion. The result is discomfort caused by improper design.

The main goal of the research presented in this paper was to find a creative design solution for more efficient protective equipment for light recreational sports, such as biking, running, roller blading, mountain climbing, vertical wall climbing, off-road mountain biking and light weight motorcycling with motorbikes up to 125 metar cubic and speed up to $150 \mathrm{~km} / \mathrm{h}$. These sports require protective equipment that will satisfy the agile nature of the sport and will provide appropriate adaptation of a gentle blow and more extreme blow. The protective equipment on the market significantly performs its intended purpose of protecting the user from knock-down, usually made of plastic material connected with elastic textile, tightly fastened with an elastic band. Unfortunately, plastic parts of the protective equipment are usually made with rough edges that couse scratches at the user's skin during normal use.

The design of sport protective equipment has to be focused on several important aspects:

Received: April 2020, Accepted: July 2020

Correspondence to: Prof. Ile Mircheski,

Faculty of Mechanical Engineering,

Karposh 2 bb, 1000 Skopje, R. North Macedonia

E-mail: ile.mircheski@mf.edu.mk

doi:10.5937/fme2004849Z

(C) Faculty of Mechanical Engineering, Belgrade. All rights reserved
- to recognize potential injury points (knees, palms, elbows, head);

- to provide free space for movement (free motions around the potential injury points);

- to reduce the effect of external impact;

- to allow maximum enjoyment while performing the sport activities.

In order to achieve better design of knee protector, we have based our research on an interdisciplinary approach where the possibilities of ergonomics and bionics methods were applied. The design process was completed in four phases:

- research and evaluation of the existing products for knee protection on the market;

- search for the possible solution from natural systems (problem-driven bio-inspiration approach);

- $\quad$ study of the ergonomics requirements for better comfort and safety (ergonomic analyses);

- concept design.

The result was an innovative design of a knee protector for recreational sports, inspired by the armadillo's shell structure, presented as a virtual 3D model, with intention to be further developed and tested as a prototype.

\section{MARKET RESEARCH}

By observing products from already established brand names, one can create expectations for a new product development. In this research three pioneering brands with a wide product range were recognized and focused onto specific products that accommodate the expectations and requirements for a more bionic inspired product with a higher ergonomic value. Those brands being: Dianese, Fox and Alpinestars. 

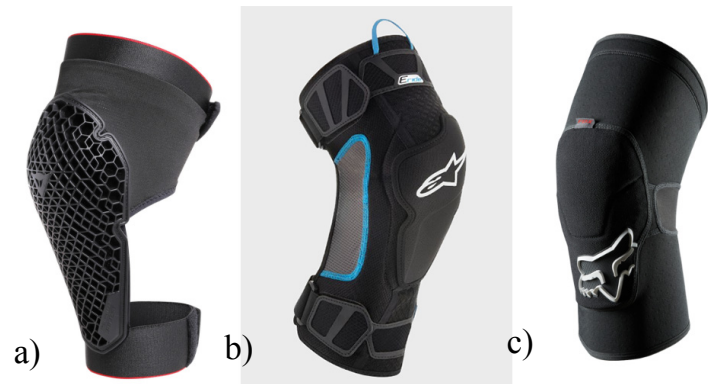

Figure 1. Knee protectors: a) Trail Skins 2 Knee Guard Lite (company Dianese, https://www.dainese.com/it/it/home/), b) E-ride knee protector (company Alpinestars, https://www.alpinestars.com//) and c) Launch enduro knee pads (company Fox, https://www.foxracing.com/)

DIANESE is an Italian manufacturer and developer of protective gear, with a primary focus on motorsports of all competitive subdivisions. However, their product range extends even towards the areas of alpine skiing, mountain cycling, competitive sailing, and since 2016 astronaut gear. It's understandable that the brand has chosen to expand their products onto activities far beyond their intentional target, however it's important to maintain course to the products they offer to more ordinary user base, rather than the specific indevelopment gear for activities out of reach for the target users. Trail Skins 2 Knee Guard Lite is a product developed in detail by the manufacturer Dianese (Fig. 1a). This model offers protection and flexibility of movements for the front of the knee. It also provides air circulation around the knee which reduces the air humidity caused by constant sweating of the user's skin.

ALPINESTARS is also an Italian manufacturer of protective gear. Contrary to the name alluding to alpine sports; the company also focuses on motor and automotive sports, such as Formula 1, MotoGP, NASCAR and it is progressing towards professional cycling within the range of Tour De France. Due to the more focused product range, the shortlisting was far easier than Dianese. E-ride knee protector (Fig. 1b) offers protection of the knee in full volume. All models focus on centralized protection of the patella with no hind elastics and straps, in order to prevent the skin from sweating while providing a comfortable bend of the entire knee. However, unlike Dianese, the selected model representative for Alpinestars doesn't not provide side protection, due to the vertically focused positioning of riders either in a fixed position or while performing cyclical movements.

And lastly, we have Fox under the scope of research. In comparison to the other two, Fox is a relatively new company stationed in the United States. As a counter reaction of the rising of Japanese protective gear manufacturers in the $60 \mathrm{~s}$, the company began as a manufacturer for $125 \mathrm{CC}$ riders, and it has steadily expanded towards mountain biking, extreme BMX biking, surfing, skiing and water skiing. The brand is highly recognizable among passionate sport enthusiasts with their highly vibrant colours. When it comes down to the product itself, we've selected Launch Enduro Knee Pads (Fig. 1c) as an appropriate representative. The model has full elastic knee coverage with no security bands or straps since it has a slip-in method of application. The plastic protective cap is fixated into the fabric itself allowing for a sleek look, but at the same time it provides a full coverage of the knee alongside some side protection.

\section{ERGONOMIC REQUIREMENTS}

After the recognition of high-quality representative products in the field of protection protective equipment for recreational extreme sports, presented in the previous phase, we established our main goal - to make better design than the design of selected products. We considered a general deficiency about all of the reviewed models - minimal flexibility of the fixed plastic shock-proof surface. In order to make the precise and reliable design requirements we had to make a serious ergonomic research.

We accepted an approach to analyze the user experience with the selected products. The users were invited to practice sport activities with all of the selected products. They were asked, after that, to fill up a survey where they had to make ranking of all of the products with scores from 1 to 5 (1- lowest and 5 highest), in accordance with the following criteria: impact protection, freedom of knee movement (mobility), comfort during practicing sport with knee protector, proper air circulation, proper fitting to the knee and price. The scores obtained on the base of the opinion of 150 survey respondents (skiers, cyclists, climbers, etc.) are presented in Table 1.

Table 1. Results of the hypothesized user experience

\begin{tabular}{|l|c|c|c|}
\hline & $\begin{array}{c}\text { Trails Skins 2 } \\
\text { Knee Guard } \\
\text { Lite }\end{array}$ & $\begin{array}{c}\text { E-Ride } \\
\text { Knee } \\
\text { Protector }\end{array}$ & $\begin{array}{c}\text { Launch } \\
\text { Enduro } \\
\text { Knee Pads }\end{array}$ \\
\hline Impact protection & 4 & 3 & 2 \\
\hline Mobility & 2 & 3 & 5 \\
\hline Comfort & 3 & 4 & 5 \\
\hline Air flow & 1 & 3 & 4 \\
\hline Fitting & 2 & 3 & 5 \\
\hline Price & $59.90 €$ & $84.95 \$$ & $59.90 \$$ \\
\hline
\end{tabular}

The obtained results from the survey were afterwards presented with spider mesh diagram (Diagram 1) with the intention to recognize the best quality product with the highest scores. They adopted the same evaluation criteria used for the conducted survey and the same rating with grades between 1 and 5 . After the evaluation process, Launch Enduro knee pads, from Fox was selected as the best rated product that offers the best ergonomics, best movement comfort and most suitable attach to the knee. The product was selected as the best example that should be followed for this research, with intention to overcome the all ergonomic features.

We adopted the main goal for this research - to provide better protection degree than the selected product. We found that application of central plastic protection cover used in the product "Trail Skins 2 Knee Guard Lite (from the company Dianese) should be also a good example to accept for our concept. 
As a result of the analyzed products, the conducted survey and spider mesh analyze, the following design requirements for the knee protector were adopted: possibility for application for extreme sports, unique appearance, flexibility, comfort, protection from injuries, easy installation, efficient air circulation that allows better extraction of the air humidity caused by sweating, affordable price.

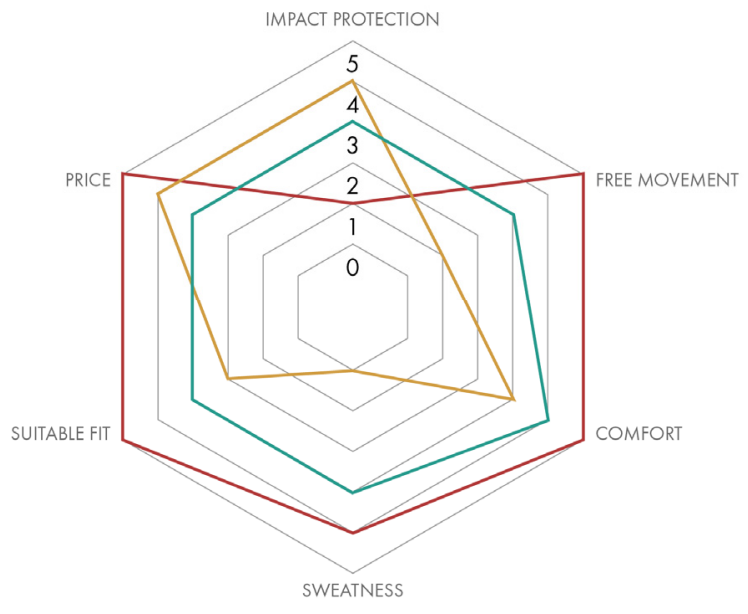

Trails Skins 2 Knee Guard

E-ride Knee Protector

Lauch Enduro Knee Pads

Diagram 1. Product evaluation with spider mesh diagram

\section{BIONIC INSPIRATION}

Bionics is an interdisciplinary science, which synthesizes the knowledge of biology and other sciences. Industrial designers, architects and engineers find the application of bionics principles and methods efficient for deriving inspiration and improving their creative thinking [1]. Designers explore natural systems by adopting one of the two main bionic strategies: solutiondriven or problem-driven approach. The first one deals with abstraction of the principle in biological systems as an inspiration for application in the product design process. The second one searches for a solution in natural systems for already recognized design problems.

Versos and Coelho propose the bi-directional bionic design method [2,3], which suggests a series of steps in the design process that could be practiced in one of the two alternative orientations considered for the bionic design process. The common steps in both directions of analysis consist of the same activities, contain the same description and are applicable for the two orientations.

Many researchers worked on developing strategies and methods for practicing biologically inspired design. Helms, Vattam and Goel $[4,5]$ propose an organizing framework for practicing of biologically inspired design, which could be applied on both problem-driven process and solution- driven process.

Other researchers worked on development of engineering solutions and strategies inspired by nature. Stevanović and Rašuo [6] made an analysis of the movement of legged biological systems with laboratory observations and measurements. On the basis of the four recognized principles of movement with the help of legs they offered a 3D model of a robot inspired by insects with six legs. Using modern software tools Solidworks and Matlab Simulink they performed a mathematical analysis of its mechanism for movement in a 3D environment. They considered that the Bionics with the assistance of modern software engineering can be a powerful tool for engineering innovations.

Gavrilović, Rašuo and others [7] made a research focused on improvement of commercial aircraft performance by reducing lift-induced drag with application of wing-tip devices. By applying several types of winglets, which are already used on commercial airplanes, they studied their influence on aircraft performance. They used different shapes of the winglets inspired of birds' wingtip feathers with their large variety in morphology.

There are several online libraries available for bionic exploration. Ask Nature [8] by Biomimicry Institute [9] is a perfect support for the designers in their efforts to recognize natural solutions to different design and engineering problems. Bionicinspiration [10] is an open source project which aim is to collect all known bionic solutions all over the world. Many bionic solutions, offered and proven over millions of years by nature, as answers for many possible design problems, are presented systematically to apply to product design by the support of creativity methods like TRIZ.

\subsection{Bio-inspiration derived from armadillo's shell}

According to the problem-driven bionic approach, after the precise description of the design problem, search for possible solution started in the frames of the affluent basin of natural systems that offers countless natural solutions. Armadillo's shell with its movements and shell structure was an excellent example for inspiration. The shell has several unique characteristics that vary depending on the geographical position of living environment of the animal. North American armadillo (Fig. 2a) with 9 hoops around the waist has an extremely high armor hardness and hard limb nails as a result of the host environment. This shell structure is an efficient protection tool from predatory birds. Brazilian Armadillo (Fig. 2b) with three hoops has not a rigid armor, but has an ability to transform the body shape into the ball as a defense mechanism.

a)
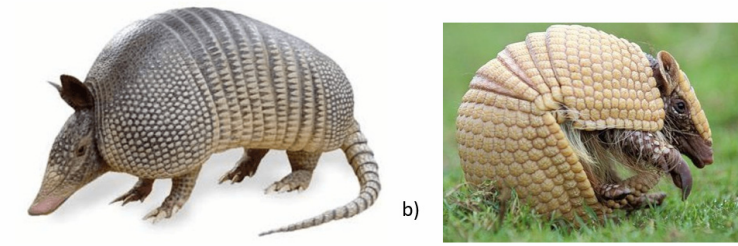

Figure 2. a) The North American armadillo and b) The Brazilian armadillo.

The two animals have similar characteristics owing to the chemical structure of the armour. According to the research of Irene H. Chen, James H. Kiang and others [11] the armour's structure is consisted of nonmineralized collagen fibres and mineral tiles. The tiles are connected with a special type of elastic fibre called Sharpeys' fibre, which contain collagen. In general, the armour, tiles and fibres are made of the same material - 
collagen. Figure 3 shows the connection arrangement of highly mineralized tiles with unmineralized collagenous Sharpeys' fibre. The fibres between the tiles allow easy bending and protection of the armadillo. The armadillo's shell is directly connected to the armadillo's skeleton, which means that the movements of the shell are directly dependant on the armadillo's movements.

a)

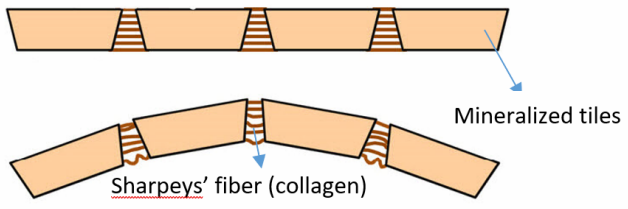

Figure 3. Shell structure a) unbended and b) bended [11]

Unlike other vertebral mammals with exoskeletal protection, the armadillo is one of the few geniuses in the animal kingdom, which has the ability to manipulate the curvature of its carapace, in order to maintain constant protection, regardless its concavity. Whilst ensuring protection, the trapezoidal tiles maintain an equidistant relationship due to the internal retraction of Sharpeys' fibers. Energy release is not present during the flexing of the carapace, due to the fact that the control and energy arises from the muscle and spinal activity.

However, the positioning of the tiles not only remains consistent and evenly distributed to uphold a perpendicular impact, but also the grid-like relationship between the tiles and Sharpeys' fiber maintain a natural flexible dermal armor. This means that the entire structure aims to absorb the impact and return to its primary position.

If one takes the muscular and skeletal structure of the armadillo and add a parallel to the human knee, such formidable application can be possible. Since we're observing bionic design, the focus is dropped on how to reapply the omnipresent impact defence system onto the knee without replicating nature's original work. The direction of extension and retraction of the knee is unidentified since the knee is symmetrical unlike the armadillo. This means that the direction of band distribution is more appropriate if it's central, instead of linear (diagram 2).

Additionally, the design should be able to re-enact the exoskeletal relationship between the knee and the knee protector by creating connecting points that mimic the spinal cord and the carapace.

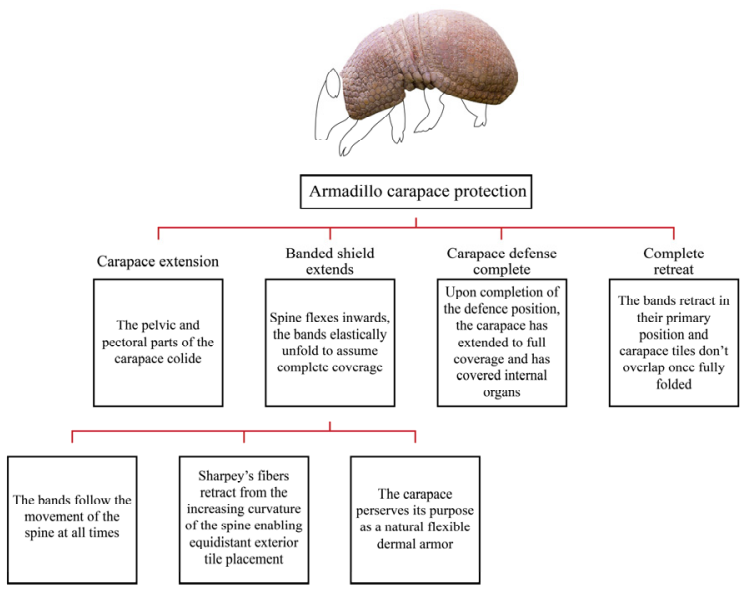

Diagram 2. Armadillo carapace protection overview
After the studied armour structure of armadillo it was considered that it could be a valuable example as an inspiration for an innovative design of knee protector for sports-men. According to the six-step bio-inspiration strategy adopted in our previous researches we made a review of the advances recognized from armadillo's shell structure that could be applied for an innovative design of different products.

Extraction of the principles of the armadillo's shell structure and their application in the design of a knee protector could ensure most of the defined features: unique appearance, flexibility, comfort, protection from injuries, easy installation, more efficient air circulation.

\section{ANTHROPOMETRIC JUSTIFICATION}

The definition of the anthropometric measurements is an important segment of the product development. The human knee can extend backwards up to an angle of $135^{\circ}$ degrees from a normal resting position and up to $20^{\circ}$ degrees when bent inwards. These extremes are called flexing and hyperextension, respectively. From a sitting position, once the knee is flexed under a $90^{\circ}$ degree, can rotate $60^{\circ}$ degrees inwards and $30^{\circ}$ degrees outwards, while extended it can complete $35^{\circ}$ degree angle when rotated inwards and $20^{\circ}$ degrees outwards. There is a slight rotation around the axis of the leg when it's in a normal standing position. The anthropometric measurements taken over from an anthropometrical reference book [12], are used for a new design of knee protector (fig. 4).
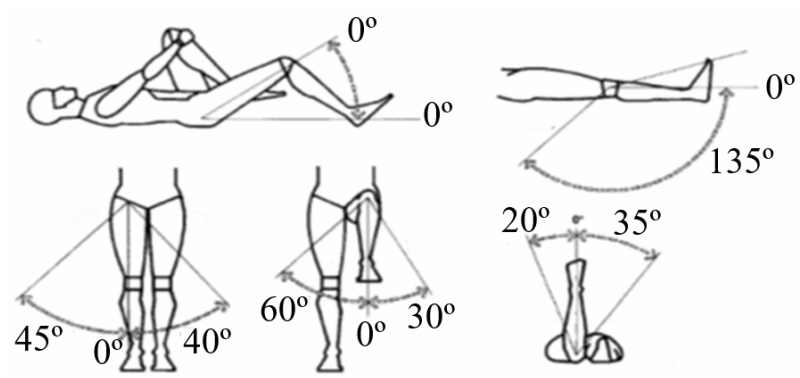

Figure 4. Movement volumes of the human knee [9]

\section{BIO-INSPIRED KNEE PROTECTOR - CONCEP- TUAL DESIGN}

The final step of the development process of the innovative design of a knee protector was concept generation. Owing to the fact that in the previous phase a promising example from nature was selected, several possible solutions were generated on the base of the armadillo's shell structure. The most encouraging concept presented on Figure 5a was selected for further development. The final concept of the knee protector is presented in details in Figure 5b. as a set of components: central protection plate, secondary protection rings, elastic connector, elastic bend belt for fastening and trouser leg.

The selected concept, presented on the Figure 5b, is inspired by the armadillo's shell structure made of tiles connected with collagen fibers. It is designed as an arrangement consisted of a central protection plate and additional protection rings interconnected with elastic bands. 


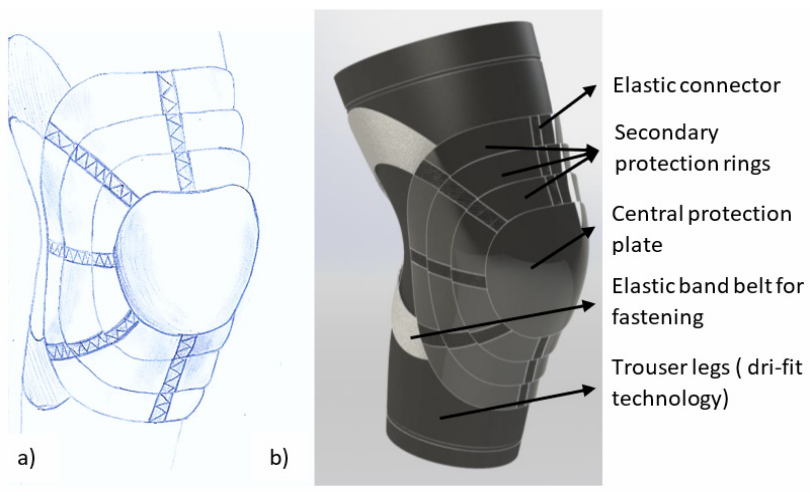

Figure 5. Product design: a) initial sketch and b) virtual 3D model with description of components

The whole assembly allows free movement of the knee owing to the specific structure where the central protection plate is intended for reception and three additional rings for suspension of the blow (external impact) during user's falls and other possible accidents. The front protection is made up of one central protection plastic plate and three levels of secondary protection consisted of three rings overlapping each other, with eight divisions, connected by elastic connectors. Behind each separation of the rings and the central part protection there is another level of elastic connectors between them and the leg. Elastic textile connector is intended to be produced of Dri-FIT material, made of polyester fabric that allows the skin to breath and does not absorb sweat during exercise. The fabric can be washed with soap and water or washed in a washing machine. This material is patented by the sports company Nike which constantly works on the problem of biodegradability and recyclability of textiles and plastics in their products, while guaranteeing quality and long service life.

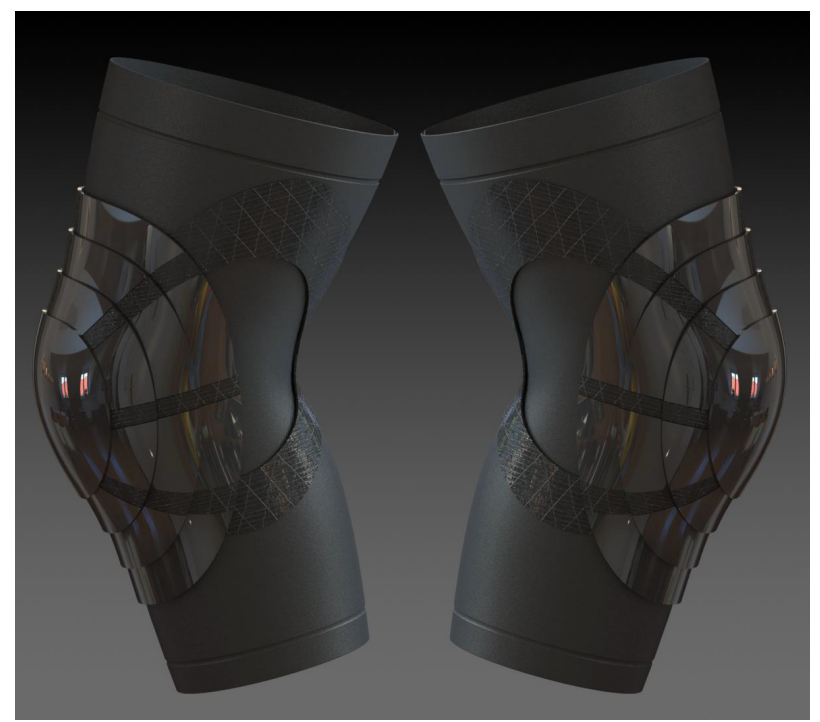

Figure 6. 3D model of the final concept of the knee protector

The final concept is presented in Figure 6. It is based on the idea of dressing up the knee protector as a sock or glove. The knee protector involves plastic elements which are the same for the top and bottom, making production cheaper and the product more competitive. The back part from knee protector has a secondary elastic coating that allows better elastic adhesion around the joint. Additional safety for the knee is obtained with four hoops around the knee, which also enable sport aesthetics.

Different positions of the protected knee are presented in Figure 7 a), bent knee 7 b) half-bent knee and $7 \mathrm{c}$ ) straight knee. In every position of the knee the knee protector enables free movement of the joint and gives ergonomic comfort in performed sport activities.

a)
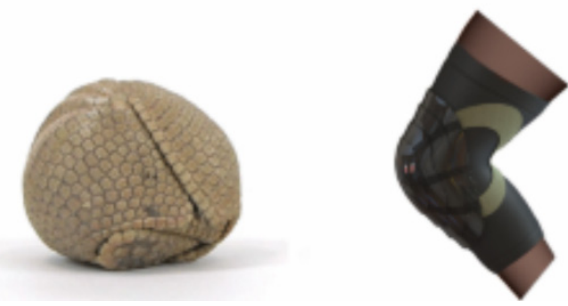

b)
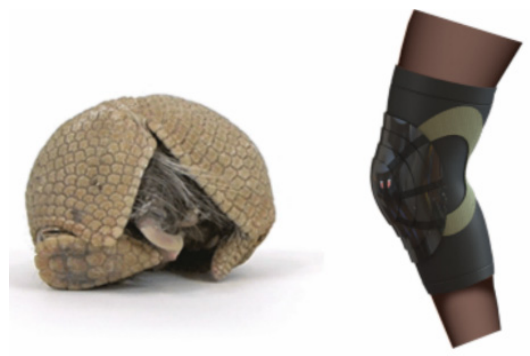

c)
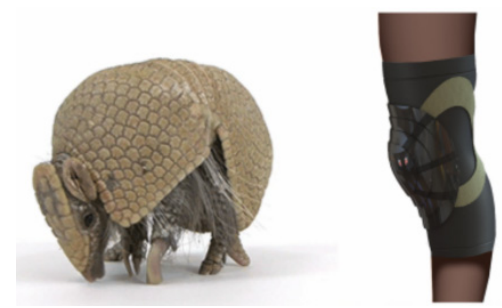

Figure 7. Different protection positions: a) bent knee, b) half-bent knee and c) straight knee

The vital aspect of our research was to ensure balance between the design of the product and its functionality for this type of products. With the presented design we expect better aesthetics, better functionality and better protection of the knee.

\section{CONCLUSION}

The knee protectors for modern recreational sports should be an integral part of any equipment arsenal in order to offer better protection, mobility, comfort, air circulation, fitting and price. The new concept design presented in this research offers improved protection impact in comparison with existing knee protectors on the market, presented in figure 1. It is achieved with one central protection plate and small plastic tiles as secondary protection rings which are made from hard plastic with carbon fiber mesh inside. In correlation with products presented in figure 1 with their properties presented in Table 1, the configuration of the new concept design of knee protector with one central protection plate and secondary protection rings offers better knee movement freedom, improved comfort during practicing sport. The air circulation or ventilation of knee for the new concept design will be same with 
product Launch Enduro knee pads from company Fox presented in figure 1. It is enabled with the use of similar textile and elastic connectors between plastic tiles. The dressing up of the new designed knee protector is the same as a dressing up of sock or glove. In comparison with existing products on the market the dressing up is easier and faster. The knee protector involves plastic elements with carbon fiber mesh inside which are the same for the top and bottom, making production cheaper and the product more competitive. For the products presented in figure $1 \mathrm{a}$ and $1 \mathrm{~b}$, an expensive tool for injection molding with bigger dimensions is needed. This tool is expensive and makes the production of the knee protector expensive and has an influence on the final product price.

The presented research is an example of how an interdisciplinary approach, where the possibilities of ergonomic and bionics methods were applied, could develop an innovative design solution. The exploration of the armadillo shell resulted in an idea to use the findings for the design of knee protector with better ergonomic, better functioning and better protection from injuries. We hope that we created a better product compared to the existing knee protectors at the market.

The next steps of our research are necessary for the design improvement. The presented concept design would be further developed in details as a 3D model that could be efficiently virtually tested with Jack - Siemens (PLM Human Modeling and Simulation Tool) for virtual ergonomics. According to the results, necessary corrections should be incorporated. The real testing should be the final stage. The 3D model would be 3D printed in several sizes for different percentiles of users. The prototype should be evaluated with real human users during sport activities. Eventual problems should be solved with tests and trials until the achievement of complete user satisfaction.

\section{ACKNOWLEDGMENT}

The research presented in this paper was developed in the frames of the educational process of the course Ergonomics and Bionics of Master studies in industrial design and marketing at the Faculty of Mechanical Engineering in Skopje.

\section{REFERENCES}

[1] Sidorenko, S.: Improvement of creativity via the six-step bio-inspiration strategy. South East European Journal of Architecture and Design, Vol. 2017, pp. 1-8, 2017, https://doi.org/10.3889 /seejad.2017.10028

[2] Versos, C. A. M., Coelho, D. A.: A Bi-directional Method for Bionic Design with Examples, Advances in Industrial Design Engineering, InTech, (doi: 10.5772/53417), 2013.

[3] Coelho, D. A., Versos, C. A. M.: A comparative analysis of six bionic design methods, International Journal of Design Engineering, Vol. 4 No. 2, pp. 114-131, 2011.
[4] Goel, A.: Is Biologically Inspired Invention Different?, Proceedings of the Sixth International Conference on Computational Creativity, June 2015, pp. 47-54.

[5] Helms, M., Vattam, S. S., Goel, A.: Biologically Inspired Design: Process and Products, Design Studies, Vol.30, No.5, pp. 606-622, 2009.

[6] Stevanović, I., Rašuo, B.: Development of a Miniature Robot Based on Experience Inspired by Nature, FME Transactions, Vol. 45, No. 1, pp. 189197, 2017.

[7] Gavrilović, N., Rašuo, B., Dulikravich, G., Parezanović, V.: Commercial aircraft performance improvement using winglets, FME Transactions, Vol. 43, No. 1, pp. 1-8, 2015.

[8] AskNature - Innovation Inspired by Nature, The Biomimicry Institute. 2016. Available at www.asknature.org/

[9] Biomimicry Institute. Biomimicry: a tool for innovation. 2007. Available at www.biomimicry institute.org/aboutus/biomimicry-a-tool-for-innovation.html

[10]BIONICINSPIRATION.ORG, 2016. Available at http://bionicinspiration.org

[11] Irene H. Chen, James H. Kiang, Victor Correa, Maria I. Lopez, Po-Yu Chen, Joanna McKittrick, Marc A. Meyers,Armadillo armor: Mechanical testing and micro-structural evaluation, Journal of the Mechanical Behavior of Biomedical Materials, Vol. 4, Issue 5, pp. 713-722, 2011

[12] Panero, J., Zelnik, M.: Antropološke mere $i$ enterijer, Građevinska knjiga, 2009, Srbija.

\section{БИО-ИНСПИРИСАН ИНОВАТИВНИ ПРИСТУП ДИЗАЈНУ ШТИТНИКА ЗА КОЛЕНА ЗА РЕКРЕАТИВНИ СПОРТ}

\section{А. Здравкова, И. Мирчески, С. Сидоренко}

Рад приказује поступак иновативног дизајнирања штитника за колена. Циљ истраживања је да се изнађе креативно решење за ефикаснију заштитну опрему за лаке рекреативне спортове. Истраживање ce базира на интердисциплинарном приступу применом могућности које пружају ергономија и бионика. Испуњење одговарајућих захтева дизајнирања остварено је истраживањем захтева тржишта за штитницима за колена. Ергономска истраживања су била усмерена на већу удобност, боље функционисање опреме и бољу заштиту од повреда. Целокупан поступак дизајнирања је био биолошки инспирисан. Базирао се на грађи љуштуре армадила која се састоји од колагенских влакана. Добијен је виртуелни 3D модел иновативног дизајна штитника за колена, са циљем даљег развоја и испитивања 3D одштампаног прототипа до фазе финалног производа. 